\title{
The Geopolitics on the Silk Road: Resurveying the Relationship of the Western Türks with Byzantium through Their Diplomatic Communications
}

\author{
Li Qiang, Stefanos Kordosis*
}

The geopolitics pertaining to the Silk Road network in the period from the 6th to the 7 th century (the final, albeit important, period of Late Antiquity) was intertwined with highly strategic dimensions. The frequent arrival of hoards of nomadic peoples from inner Eurasia at the borders of the existing sedentary empires and their encounters and interactions formed the complicated political ecology of the period. These empires attempted to take advantage of the newly shaped situation arising after such great movements strategically, each in their own interest. How did they achieve their goals and what problems were they confronted with? In this paper, I will focus on the relations the Western Türks had with Byzantium and use it as an example in order to resurvey these complicated geopolitics. In the first part, attention will be given to the collection of Byzantine literature concerning the Western Türks. Then, on the basis of the sources, the four main exchanges of delegations between the Western Türks and Byzantium will be discussed, in which the important status of the 563 embassy - as it was the first Türk delegation sent to Byzantium - will be emphasized. The possible motives behind the dispatch of the delegations and the repercussions they had will be presented. Finally, through reviewing the diplomatic communication between the Western Türks and Byzantium, attention will be turned to the general picture of geopolitics along the Silk Road, claiming that the great empire of the West - similar to today's superpowers - by means of their resources (mainly diplomacy) manipulated the geopolitics on the Silk Road, especially the nomadic people pursuing their own survival and interests, who were only treated as pieces on a chessboard for keeping the balance with the rest of the superpowers.

Keywords: Western Türks; Byzantium; Geopolitics; Diplomacy; Nomads; Silk Road

* Correspondence Details: Dr. Li Qiang, Institute for the History of Ancient Civilizations (IHAC), Northeast Normal University, Renmin Str. 5268, Changchun, 130024, China. Email: liq762@hotmail.com; Dr. Stefanos Kordosis, Academic Associate, International Hellenic University, School of Humanities, s.kordosis@ihu.edu.gr.

1 No wonder that until now Silk Road is the most popular public and research term of the 21st century on the Eurasian continent; not only it is an excellent example of global history, but also of China's "Belt and Road Initiative«. The recent relevant publications are as follows: Preiser-Kapeller, Jenseits; Frankopan, Silk Road; Hansen, Silk Road; Liu, Silk Road. 
Since the 550s, following the collapse of the Rouran Empire (in Chinese characters 柔然, pronounced róu rán), ${ }^{2}$ the Türks (in Chinese characters突厥, pronounced tūjué), a nomadic people, came to prominence (552 AD) to the north of China, then further, after defeating the Hephthalite Empire (in Chinese characters 嚈哒, pronounced yàndā), fast becoming a highly influential military power in the middle section of the Silk Road network. ${ }^{3}$ In this period, the political universe comprised three strong empires (Byzantium, Sasanian Persia, and China) around which other minor nomadic peoples gravitated, forming a complex geopolitical network along the Silk Road. The Türks were a prominent player, having a key role in this network. The western part of the Türks, namely, the Western Türks, were much involved in the events related to the western part of this network for the next two centuries, especially as regards the balance of power between the Persian Sasanian Empire and Byzantium. After a short honeymoon with the Sasanians, which culminated in the joint war against the Hephthalites, ${ }^{4}$ the Persians broke their alliance with the Western Türks in fear of their increasing ability to compete for territory and in economic terms. ${ }^{5}$ Faced with that change, and following the suggestion of their subordinate Sogdian leaders, the Western Türks sought diplomatic contacts with Byzantium, which was the other superpower controlling the western terminus of the Silk Road and the main foe of the Sasanians. They, thus, formed a new military alliance against their common enemy, the Sasanians. However, due to geopolitical fluctuations along the Silk Road, this constellation was not always steady, hence, the relations between the Western Türks and Byzantium were neither smooth nor long (they broke down right after the Byzantine embassy of Valentinus in 575-576, when the Türks took over the Bosporus in Crimea, although the bilateral relationship was probably resumed in $584,{ }^{6}$ and later on in 620s). It is understood, through the examination of the relationship between the Western Türks and Byzantium, that, on the Silk Road, the superpowers' interest always determined the direction of the changes in geopolitics, and the nomadic peoples, being minor polities living short geopolitical cycles, were treated by the former only as pieces on a chessboard and never as close friends or steady allies, but as ephemeral partners with whom, occasionally, they had to be very cautious. On the other side, the nomadic peoples understood their role and weaknesses, but tried to survive in a volatile environment, maximizing the profits gained from the superpowers. The Silk Road sustained a political ecosystem that, visibly and invisibly, promoted interaction and communication among various agents in the areas of politics, culture, commerce and religion in late antique Eurasia.

2 The Rouran Empire was a steppe Khaganate active to the north of China from the late 4th century until the middle of the 6th century, see Nikolay, From Tribal Confederation, 149-169; Grousset, Empire of the Steppes, 60-61.

3 Kordosis, Turks; Golden, Introduction; Sinor, First Türk Empire; Moravcsik, Byzantinoturcica; Chavannes, Documents.

4 In 560s, Sasanian Persia had an alliance with the Western Türks aiming at defeating the Hephthalite Empire, see Litvinsky, Hephthalite Empire, 147; Kurbanov, Hephthalites, 186-187.

5 Erdemir, Turko-Byzantine Relations, 427-428; Frendo, Turkish Factor.

6 Georgios Kardaras mentions that the historian John Ephesus recorded that when the Avars sacked the city of Anchialos, the Türks attacked on their rear, which forced them to buy off the disengagement of the Türks. Kardaras believes that this means Emperor Maurice resumed relations with the Türks, see his Kardaras, Byzantium and the Avars, 53; Tzimou, Byzantine-Türk alliance, 9. Michael the Syrian also recorded news about this Türk attack on the Avars, see Michel le Syrien, Chronique, trans. Chabot, 363. 
The relations between the Western Türks and Byzantium have been well studied by scholars from different fields, ${ }^{7}$ but there is always room for some new interpretations or re-interpretations or for addressing questions regarding the issue that may not have been addressed yet. This article intends to bring together the Byzantine sources related to the topic, with the aim of clarifying Turco-Byzantine relations as they are manifested through the official exchanges of diplomatic delegations and shedding new light on their nature and on the geopolitics along the Silk Road. With this in mind, the paper is separated into three parts: firstly, the Byzantine literature concerning the Western Türks; secondly, analysis of the four main diplomatic activities followed by a discussion on the nature of the Western Türk-Byzantium relations and, thirdly the basic principles of the geopolitics on the Silk Road.

\section{Byzantine literature on the Western Türks}

Information concerning the Western Türks is found in the following Byzantine sources: the History of Theophanes Byzantios, ${ }^{8}$ the Ecclesiastical History of Evagrius Scholasticus, ${ }^{9}$ the History of Menander Protector, ${ }^{10}$ the History of John of Epiphania, ${ }^{11}$ the Ecclesiastical History of John of Ephesus, ${ }^{12}$ Maurice's Strategikon, ${ }^{13}$ the History of Theophylact Simocatta, ${ }^{14}$ the Short History of Nicephoros Patriarch of Constantinople, ${ }^{15}$ and the Chronicle of Theophanes Confessor. ${ }^{16}$ Despite the fact that the times of completion of each of these works and their subjects vary greatly, they preserve information of importance for analyzing the interactions between the Türks and Byzantium. Most of the works were written in the period from the late 6th century to the 7th century: ${ }^{17}$ the histories of Theophanes Byzantios, Evagrius Scholasticus, of Menander Protector and of John Epiphania were written towards the end of the 6th century. Maurice's Strategikon and the History of Theophylact Simocatta were completed in the first half of the 7th century. The Short History of Nicephoros Patriarch of Constantinople was written at the end of the 8th century and the Chronicle of Theophanes Confessor at the beginning of the 9th century, respectively, incorporating lost sources from the 7 th century; they are regarded as the key primary sources for the 7th century.

7 There are plenty of studies on this topic; therefore, I only list the most specialized bibliography: Macartney, Greek Sources, 266-275; Moravcsik, Byzantinoturcica; Sinor, Establishment and Dissolution, 285-316; Sinor, First Türk Empire, 321-330; Erdemir, Turko-Byzantine Relations, 423-429; Kordosis, Turks; Whittow, Byzantium's Eurasian Policy, 271-286.

8 Photius, Myriobiblon, PG 103; Photius, Library, trans. Freese, 73-75.

9 Evagrius, Ecclesiastical History, ed. Bidez and Parmentier; Evagrius Scholasticus, Ecclesiastical History, trans. Whitby

10 Menander Protector, History, ed. Blockley.

11 John of Epiphania, Fragmenta, ed. Müller, 272-276; John of Epiphania, History, trans. Kennedy.

12 John of Ephesus, Ecclesiastical History, trans. Smith.

13 Maurice, Strategikon, ed. Dennis and Gamillscheg; Maurice, Maurice's Strategikon, trans. Dennis.

14 Theophylact Simocatta, Historiarum, ed. Bekker; Theophylact Simocatta, History, trans. Whitby and Whitby

15 Nikephoros, Short History, ed. Mango.

16 Theophanes Confessor, Chronographia, ed. Classen; Theophanes Confessor, Chronicle, trans. Mango and Scott.

17 For the introduction and analysis of these works, refer to: Treadgold, Early Byzantine Historians; Treadgold, Medieval Byzantine Historians; Karpozilos, Byzantine Historians and Chronographers, vol. 1, vol. 2. 
These works belong to different literary forms and they present us with different facets of the Western Türks and their relations with Byzantium. The History of Menander Protector and the History of Theophylact Simocatta are works of history, so their focus is on the secular history and the details of events, especially as regards the subject at hand, the embassies between the Western Türks and Byzantium. Maurice's Strategikon, as a military treatise, concentrates on the military organization and training of the various nations surrounding Byzantium, hence, it provides us with descriptions on the military issues and, moreover, with the basic characteristics of the Western Türks. The Ecclesiastical History of Evagrius Scholasticus and the Ecclesiastical History of John of Ephesus are Church histories and only sporadically related to secular history. The Chronicle of Theophanes Confessor, although a secular work, records the events from a greater chronological distance, so these last works are not central to this study.

\section{Analysis of the four embassies between the Western Türks and Byzantium}

The interaction between the Western Türks and Byzantium in Byzantine literature revolves around the exchange of delegations. There are four delegations described in detail, two of which were dispatched by the Western Türks to Constantinople and another two that were sent from the Byzantines to the Türks. Previous studies regarding the embassies between the Western Türks and Byzantium mainly focus on the 568 AD embassy of the Western Türks headed by the Sogdian Maniakh, the 569 AD embassy of Byzantium, with Zemarchus at its head and the 575-576 AD Byzantine embassy headed by Valentinus, while the 563 AD embassy of the Western Türks has been neglected by the majority. ${ }^{18}$ In addition, the consequences of the three detailed embassies have not yet been exhausted. All of these can be further analyzed and supplemented with the fertile Byzantine sources.

The first delegation from the Western Türks to Byzantium must be dated to $563 \mathrm{AD} .{ }^{19}$ The majority of the published works which refer to the contacts between the Western Türks and Byzantium are inclined to set the first contact in 568, the year of the visit of Maniakh's delegation, attested in the History of Menander Protector. ${ }^{20}$ However, according to the records of Theophanes Byzantios and Theophanes Confessor, the first embassy from the Western Türks was received in Constantinople in 563. Theophanes Byzantios mentions that »the Turks, fomerly called Massagetae and Kirmikhiones, by the Persians, who lived to the east of Tanais (Don), at this time sent a delegation with gifts to the emperor Justin [Justinian?], beseeching him not to receive the Avars. Justin [Justinian?] accepted the gifts, received the ambassadors

18 Only few scholars noticed this embassy, the details of which will be discussed below.

19 Many scholars are baffled by the Purum embassy (Romans/Byzantium) mentioned in the Orhon Kül Tegin inscription (old Turkic), referring to a delegation sent for the funerary ceremonies related to the death of the first Türk Khagan Bumin (the English translation of the inscription is referred to in Ross, Orkhon Inscriptions). The delegation is unverified by any relevant Byzantine source, see Erdemir, Turko-Byzantine Relations, 425; Kordosis, Turks, 92. The Chinese scholar Zhang Xushan suggests that this Byzantine embassy was the delegation under Valentinus, see Zhang, Studies on the Relations, 255. Mark Whittow suggests that the Western Türks could be known to Byzantium when the Avars first arrived in Byzantium in 558, see Whittow, Byzantium's Eurasian Policy, 271-272.

20 Menander Protector, History, ed. Blockley, 111-117. There are still scholars who insist on the 568 embassy being the first Turkish embassy; for more on that, see Parker, Origin of the Turks, 439; Sinor, First Türk Empire, 328; Macartney, Greek Sources, 266-275; Kordosis, Turks, 88-94, etc. 
kindly, and dismissed them. ${ }^{21}$ Theophanes Confessor provides another piece of interesting information: »In the same month [July, 563] envoys arrived (in Constantinople) from Askel, king of the Hermichiones, who dwell inland of the barbarian nation near the Ocean. $\aleph^{22}$ Here the Kirmikhiones should be understood as the Hermichiones. Combing the two piceces of information, we can deduce the following conclusion: Kirmikhiones=Hermichiones=Türks. However, scholars have not arrived at an agreement on this hypothesis. Chavannes proposes that the Kirmichiones were pseudo-Avars. ${ }^{23} \mathrm{C}$. A. Macartney holds that the term »Türks « was a generic term used to describe the people who lived to the north-west of Persia, hence the Kirmikhiones who lived there were given this appellation, but were not the actual Türks. ${ }^{24}$ Stefanos Kordosis has suggested that it is more likely that the embassy was Türk. ${ }^{25} \mathrm{D}$. Sinor, the distinguished scholar on the history of the Türks, in one of his later works concludes the following: "The first Türk delegation known to us arrived in Constantinople in 563. According to Theophanes (Confessor) it had been dispactched by a certain Askel, king of the Kermikhions. As mentioned earlier, the Persians called the Türks by that name, a practice that may have its roots in the incorporation into the Türk empire of the 'red' Hephthalites. Be that as it may, Askel is the original form of the name of the first tribe of the confederation called by the Chinese Nushih-pi. This was the westmost tribe group of the Western Türk and the name Askel was applied indifferently to the tribe or to its ruler. ${ }^{26}$ In consideration of the above scholars' views, it is obvious that it is hard to determine the exact ethnological identity of the Kirmikhiones or Hermichiones, yet, one thing is sure: that the Kirmikhiones or Hermichiones were at least in a close relationship with the Western Türks, as the Türks were a relatively loose federation of tribes. ${ }^{27}$ We can, therefore, accept the view of D. Sinor that the Kirmikhiones or Hermichiones were one of the tribal federations of the Western Türks, hence, it is reasonable to accept the conclusion that a Kirmikhiones embassy was sent by the Western Türks to Byzantium, and that it was labelled Türk, just as the the Sogdians, being subjects of the Western Türks, always served as Türk envoys to Persia and Byzantium.

Now arises the following question: do the two sources point to the same delegation? The answer is positive. Sinor, actually, has taken it for granted..$^{28}$ The key for this identification is the time of the embassy's arrival, and the main evidence is the issue of the Avars. Theophanes Byzantios records that Justin (Justinian?) accepted the Türk (Kirmikhiones) delegation kindly. This embassy requested the Byzantine emperor not to receive the Avars, and the request was granted by the emperor, since later, when the Avars arrived at the Roman borders and asked to live in Pannonia under peace bonds with the Byzantines, their request

24 Macartney, Greek Sources, 266-275.

25 Kordosis, Turks, 91. See also Kordosis, Byzantine-Turkic relations, 296-312, esp. 298, where it is related to the Byzantine Avar Policy.

26 Sinor, First Türk Empire, 328.

27 Golden, Imperial Ideology, 50-53; Golden, Nomads, 47.

28 Sinor, First Türk Empire, 328. 
was rejected by the Byzantine emperor. ${ }^{29}$ Here, the important event is that the Avars' request for lands in Pannonia was expressed after this embassy. The source mentions that the first Avar delegation to Byzantium was received in 558 - at that time, the Avars had just arrived in the Caucasus region, where the land of the Alans was - then, the same source mentions that after being treated well by Byzantium and fighting for the empire, the Avars came again requesting lands from the Byzantines, in order to settle. This time Emperor Justinian »was planning to settle the tribe on the land which was earlier inhabited by the Heruls, which is called Second Pannonia. If they had agreed, the emperor would have granted this. But the Avars were unwilling to live outside Scythia, since, I suppose, they were greatly attached to the place. $\aleph^{30}$ So, the Avars' request for land appears in two sources and is the same story, though told differently. Accordingly, we can conclude that this Türk embassy must have taken place after 558, since the first Avar embassy was well received by the Byzantine Empire. In addition, Menander Protector mentions that after hearing of the flight of the Avars and the great loss suffered by them, the Khagan of the Western Türks, Silziboulos, ${ }^{31}$ took an oath that he would attack the Avars after his war with the Hephthalites, which was ongoing at that time, had finished. ${ }^{32}$ The war is supposed to have started after 555 and finished earlier than $565 .{ }^{33}$ Hence, Silziboulos' oath was also given between 555 and 565, a period which includes the time the Türk (Kimikhiones) embassy came to negotiate with the Byzantine emperor Justinian on the issue of the Avars, after which the Avars' new request - following their first embassy in 558 - was rejected. Considering that the records of Theophanes Confessor place the Hermichione embassy's arrival in 563, it may be deduced that the embassies mentioned by the two Theophanes must be the same one. The whole background behind the $563 \mathrm{em}-$ bassy can be outlined as follows: the Avars were subordinates (slaves) of the Western Türks. When the Western Türks were at war with the Hephthalites, in 558, after causing damage to the Western Türks ${ }^{34}$ the Avars ran away from the latter to the land of the Alans, who reported the event to Byzantium. After that, an Avar delegation was invited to Constantinople and was well received with gifts on the part of the Byzantine emperor. After hearing of the flight of the Avars, Silziboulos, the leader of the Western Türks, became angry. ${ }^{35}$ Being himself busy with the war against the Hephthalites, he tasked his tribal "foederati«, the Kirmikhiones, to act as the Türks' ambassadors to Byzantium, and came to an agreement with the Byzantine

29 Photius, Myriobiblon, PG 103, 137; Photius, Library, trans. Freese, 73.

30 Menander Protector, History, ed. Blockley, 52-53.

31 In the Orkhon inscriptions, his name is mentioned as Isämi (Istemi), in Chinese texts as shìdiănmì, see Ross, Orkhon Inscriptions, 864, Ouyang and Song, New Book of Tang, vol. 215b, second part. For the identification of Silziboulos with Istemi, see Kordosis, Turks, 96, footnote 5.

32 Menander Protector, History, ed. Blockley, 46-47.

33 Kordosis, Turks, 83-84, footnote 32

34 Evagrius mentions that the Avars »had fled en masse from their neighbours the Türks after being ill-treated by them, and had come to the Bosporus, " Evagrius, Ecclesiastical History, ed. Bidez and Parmentier, 196; Evagrius Scholasticus, Ecclesiastical History, trans. Whitby, 255.

35 Menander Protector mentions that Silziboulos, the ruler of the Türks, having learnt of the Avars' retreat after an attack on the Türks, sent the following message to Byzantium: »The Avars are not birds, to escape Türk swords by flying through the air; they are not fish, to dive into the water and disappear in the depths of the sea; they wander over the surface of the earth. When I finish the war with the Hephthalites I shall attack the Avars, and they will not escape my forces, « Menander Protector, History, ed. Blockley, 46-47. 
emperor that the Avars would not be received and that the Byzantine emperor should not reach an agreement with them. Accordingly when the Avars appeared again, requesting land for settlement, the Byzantine emperor Justinian rejected their request ${ }^{36}$ and the relations between Byzantium and the Avars became hostile. ${ }^{37}$ Actually, later on we will see that the first Türk embassy set up an advantegous foundation for the future mutual communication and alliance bettween the Western Türks and Byzantium.

The second Western Türks' delegation took place in 568. Like the first one, it was also not led by a Türk, but by their Sogdian subjects. According to the information preserved in Menander Protector, following the suggestions of the Sogdian leader, Maniakh, in 568, the Western Türk Khagan Sizaboulos (alternative spelling of Silziboulos) dispatched a delegation to Byzantium to sue for friendship, ${ }^{38}$ led by Maniakh himself. The causes of this emabssy have been discussed at length, with scholars quoting the words of Menander Protector: on the one hand, the Sasanians rejected in a harsh way the Western Türks' proposal to allow the Sogdians, who were subjects of the Türks, to sell without any hindrance raw silk within the Sasanian Persian territory; ${ }^{39}$ on the other hand, the Sogdians suggested that the Western Türks »cultivate friendship with the Romans and send their raw silk for sale to them because they made more use of of it than other people.$^{40}$ Here, we can see the Western Türks' strategy: always try to make an alliance with a superpower and get support. In light of the events mentioned previously, I believe that a resolution of the Avar issue was also the goal of this embassy. As mentioned above, Silziboulos had taken an oath to pursue the Avars, which was mirrored in the 563 Türk (Kirmichiones) embassy to Byzantium. It is clear that the issue of the Avars was an important concern for the Western Türks and that it had not been resolved. In the 568 embassy, the Avars were mentioned again.»The emperor asked, 'Tell me how large a multitude of Avars revolted from Turkish rule and whether any remain subject to you' 'There are, O Emperor, some who still adhere to us. Those who fled number, I think, around twenty thousand'. ${ }^{41}$ From this, we can see that the Avar issue was a sensitve matter, and it had been known to Byzantium since the first embassy (563), and surely it could not have been bypassed. The hatred of the Western Türks for the Avars and the Western Türks'

36 Theophanes Byzantios recorded the emperor's treatment of the Avars: „When the Avars subsequently approached Justin (Justinian?), requesting permission to inhabit Pannonia and desiring to conclude peace, he refused, owing to the agreement he had made with the Turks«, in Photius, Myriobiblon, PG 103, 137; Photius, Library, trans. Freese, 73 .

37 Menander Protector mentions for the same event that since Justinian did not accept Avars' request for Pannonia, hostility broke out between them, see Menander Protector, History, ed. Blockley, 52-53.

38 Menander Protector, History, ed. Blockley, 111-117.

39 Menander Protector has mentioned that, before this embassy, the Western Turks had sent two embassies to the Sasanian Empire for the right to sell the silk freely and also to establish an alliance between them, but the Sasanians rejected and also humiliated them: the silk of the first embassy was burnt in front of the Sogdians, and the envoys of the second embassy were poisoned, see Menander Protector, History, ed. Blockley, 111-113.

40 Menander Protector, History, ed. Blockley, 114-115.

41 Menander Protector, History, ed. Blockley, 114-117. 
tradition of continuously pursuing enemies ${ }^{42}$ were one of the issues raised in this meeting. On the basis of the talks during the first visit and of their common gains, naturally, the two sides successfully reached an agreement for an alliance. Hence, the framework of the second Western Türk delegation can be outlined like this: the Sogdians wanted to sell raw silk freely in the lands of Sasanian Persia and therefore they pursuaded their new lord, the Western Türks, to negotiate with the Sasanians. In the meantime, after the war with the Hephthalites, the rising Western Türks wanted to extend their influcence and achieve more gains in the Silk Road network; however, this goal of the Western Türks and the Sogdians met with harsh rejection from the Sasanians. Under these circumstances, the Sogdians requested the Western Türks to establish a relationship with the enemy of the Sasanians and also a major consumer of silk products, Byzantium. The Western Türks sent the 568 embassy to realize their purpose: preventing the Sasanians from trading silk directly with Byzantium; establishing the Western Türk-Byzantine alliance for dealing with the Sasanians, and solving the issue of the Avars. The result is that a Western Türk-Byzantine alliance was established, at a time when the Avars had a poor relationship with Byzantium. ${ }^{43}$ The only dark spot in the talks was the moment when the Türks (Sogdians?) were disppointed as the Byzantine Emperor Justin II demonstrated to them that the Byzantines had mastered the skill of raising silkworms and of producing silk. ${ }^{44}$

The 569 Byzantine embassy to the Türks came in response, sent to the Golden Mountain of the Western Türks. It may be considered the first formal embassy from Byzantium. This embassy was led by Zemarchus the Cilician, the magister militum per orientem (commander of the eastern field army), a rank which demonstrates that Byzantium paid special attention to the delegation and to the alliance with the Western Türks. This embassy was well recorded by Menander Protector, while information about it was also preserved in other sources: the History of Theophanes Byzantios and the Ecclesiastical History of John of Ephesus. Although the History of Theophanes Byzantios only mentioned this embassy briefly, ${ }^{45}$ it can be used as circumstantial evidence; the Ecclesiastical History of John of Ephesus recounts the details of an important scene of Zemarchus' dinner with the Khagan of the Western Türks. For this event, Menander Protector records that, when Zemerchus arrived at the camp of the Western Türks, he was invited by Silziboulos (Istemi) to observe a raid against the Sasanians.

42 It is mentioned in the Strategikon of Maurice: "When they make their enemy take to flight, they put everything else aside, and are not content, as the Persians, the Romans, and other peoples, with pursuing them a causable distance and plundering their goods, but they do not let up at all until they have achieved the complete destruction of their enemies, and they employed every means to this end, "Maurice, Strategikon, ed. Dennis and Gamillscheg, 364; Maurice, Strategikon, trans. Dennis, 117.

43 Menander Protector, referring to Justin II, reports that the latter criticized the greed of the Avars and rejected their unreasonable demands: "I shall never need an alliance with you, nor shall you receive from us any other than what we wish to give, and that as a free gift for your service, not as you expect, a tax upon us, « see Menander Protector, History, ed. Blockley, 92-97. Corippus also mentions Justin II accepting this Avar embassy, but he gave the exact date as 565, Corippus, In Laudem Iustini, ed. Cameron, 100-101.

44 Theophanes Byzantios mentions that the Byzantine emperor Justin showed the Turk how the worms bred and how silk was made, and also mentioned that the Turks had possession of the market and harbors of the Seres, formerly held by the Persians. This probably happened during the 568 embassy, see Photius, Myriobiblon, PG 103, 137; Photius, Library, trans. Freese, 74.

45 Photius, Myriobiblon, PG 103, 137; Photius, Library, trans. Freese, 74. 
When they camped in Talas, Sasanian envoys approached, and they dined together with the Khagan. During the dinner, the Byzantines were treated as honorable guests, but the Sasanians envoys were ill-treated. The Sasanian envoys were angry and argued with the Khagan. ${ }^{46}$ Thus Menander Protector recorded the event without further detail, while John of Ephesus provided more details about it. When the Khagan of the Western Türks asked the Byzantine envoys if the claim by the Persian envoys that »the Roman emperor was their slave, and pays annual tribute " was right, Zemarchus refuted it by saying that the Roman emperor Traian conquerred the Persian land, and that the Persians also worshipped Traian's statue in Persia. ${ }^{47}$ The Persian could not deny the fact, therefore the Khagan rebuked the Persian envoys as liars. After this, the Persian envoys returned home and reported their treament to their king. The Sasanian monarch believed that the Byzantines were responsible for the breaking up of his relations with the Western Türks, which increased his hostility toward Byzantium. ${ }^{48}$ The meeting was recorded by Menander Protector and John of Ephesus, but the latter provides the vivid scene of the event, showing the tense situation and the attitudes held by the Western Türks, the Byzantines, and the Sasanians. We can surmise that this Byzantine embassy was an important one for Byzantium, being a response to the one sent by the Türks, and it was given much attention so as to stengthen Byzantium's alliance with the Western Türks in a period when Justin II was faced with both the hostile Avars and the Sasanians, whose annual payment he had cancelled. ${ }^{49}$ For the Western Türks' part, they were at war with Persia. The Sasanian enovys wanted to prevent the Western Türk-Byzantine alliance, but they failed.

The return course followed by Zemarchus also deserves to be reviewed. Failing in destroying the alliance, the Sasanians intended to ambush the Byzantine delegation on their way back home. Previous studies did not expound the causes behind this, since the main narrator of the embassy, Menander Protector, never mentioned them. The event was recounted by Menander Protector as follows: In 571, Zemarchus and his men finished their mission and returned, and when passing by the land of the Alans, they were informed by the Alans ${ }^{50}$ that the Sasanians intended to ambush them in Suania. Then the embassy made a detour home by the road called Dareine. ${ }^{51}$ The works of John of Epiphania, Theophylact Simocatta and Theophanes Confessor also record this embassy, and their information provides evidence for the causes of the ambush. Theophanes Confessor mentions that, "There was another reason which disturbed Chosroes. For at that time [571] the Huns, whom we are accustomed to call Turks, sent an embassy to Justin via the territory of the Alans. « $^{52}$ Then John of Epiphania mentions that "the causes of their (Byzantium and Sasanians) strife with one another were as such: ....as the Turks had sent envoys to the Romans to which the emperor Justin had responded sending Zemarchus, a member of the Senate, back with them again, the Persians planned

\footnotetext{
46 Menander Protector, History, ed. Blockley, 121-123.

47 Michel le Syrien, Chronique, trans. Chabot, 315.

48 John of Ephesus, Ecclesiastical History, trans. Smith, 426-427.

49 Whitby, Successors of Justinian, 87.

50 They were first informed by the Ugurs that the Sasanian would ambush them, but it did not happen, see Menander Protector, History, ed. Blockley, 124-125.

51 Menander Protector, History, ed. Blockley, 126-127.

52 Theophanes Confessor, Chronographia, ed. Classen, 378; Theophanes Confessor, Chronicle, trans. Mango and Scott, 362 .
} 
to bribe the Alans through whose lands they were about to make their passage to become an obstruct Zemarchus and the Romans and Turks with him. ${ }^{53}$ Theophylact Simocatta reports similar information, but he used this as the cause of Sasanians' war with Byzantium. ${ }^{54}$ These sources, therefore, provide us with the direct cause for Sasanians ambushing the 569 embassy. The reason was that the Western Türks' envoys went together with this Byzantine embassy to Byzantium, and the Sasanians wanted to stop it. Furthermore, Michael Whitby's comment reveals another potential cause, i.e.: »The Romans and Türks had probably already agreed to launch a concerted attack on Persia (frr. 20,32), and the possibility of such joint action would have been enough to persuade the Persians to try to interfere with the embassy, « ${ }^{55}$ Mark Whittow, meanwhile, directly suggests that this embassy reached an agreement for a joint attack on the Persians planned for $573 .{ }^{56}$ Hence, combining all the sources together it is clear that Zemarchus's embassy led to the consolidation of the Western Türk-Byzantine alliance. After that, the Khagan sent another Türk embassy, following the one returning under Zemarchus, for further coordination against the Sasanians. The disappointing news from the Persian embassy made the Sasanian ruler angry, leading him to seek new ways to disrupt any further cooperation between the Western Türks and Byzantium. The Sasanians would soon move to pre-empt the attack, as can be inferred from their attack against the Himyarites in the south-west of the Arabian Peninsula, and from the revolt of the Armenians. ${ }^{57}$

After the 569 Byzantine embassy, traces of other diplomatic exchanges are preserved in the sources. Among them, the most detailed and, also, crucial is the 575-576 Byzantine delegation under Valentinus. This embassy marks the end of the short "honeymoon « between the Western Türks and Byzantium. Valentinus had three goals: 1) to inform to the Western Türks that Tiberius had become Caesar; 2) to reinforce the alliance between the Western Türks and Byzantium; 3) to request an army from the Western Türks to participate in the war against the Sasanians..$^{58}$ Although based on good intentions, this embassy failed totally. The envoys were treated badly by the the Western Türks and the alliance was broken. First, the Western Türk leader Turxanthus ${ }^{59}$ criticized the Byzantines as being treacherous and unreliable since they had: 1) signed treaties with the Türks' enemy the Avars; and 2) hidden knowledge of the road from the land of the Western Türks to Byzantium. Consequently, he forced the Byzantine envoys to cut their faces at the funeral ceremony of Silzibuolos (Istemi) in order to humiliate them in this way. ${ }^{60}$ During this embassy, Turxanthus went even further and attacked Bosphorus, a Crimean city subordinated to Byzantium. ${ }^{61}$ It is, hence, clear that Valentinus'

53 John of Epiphania, Fragmenta, ed. Müller, 274; John of Epiphania, History, trans. Kennedy, part 1, 2.

54 Theophylact Simocatta, Historiarum, ed. Bekker, 132; Theophylact Simocatta, History, trans. Whitby and Whitby, 86.

55 Theophylact Simocatta, History, trans. Whitby and Whitby, 86; Whitby, Successors of Justinian, 92.

56 Whittow, Byzantium's Eurasian Policy, 272.

57 The Himyarites had been subject to the Axumites and were Roman allies, but then a Persian-supported pretender to the Himyarite throne was installed and thereafter a Persian governor imposed, quoted from Theophylact Simocatta, History, trans. Whitby and Whitby, 85, footnote 37.

58 Menander Protector, History, ed. Blockley, 172-173.

59 At the time, the new leader of the Western Türks was Tardu, son of Istemi. Turxanthus was only governor prince, ranking under him, and he was probably Tardu's younger brother, see Sinor, Establishment and Dissolution, 304.

60 Menander Protector, History, ed. Blockley, 176-177.

61 Menander Protector, History, ed. Blockley, 178-179. 
embassy did not fulfil its mission, and the alliance of the Western Türks and Byzantium was broken. In view of their previous relations, it seems that the ostensible cause for the relation's collapse was Byzantium's ambiguous relationship with the Avars. However the esential cause must have been the fact that the Western Türks realized the Byzantine strategy. The Western Türks wanted to attack their »slaves «, the "runway « Avars, ${ }^{62}$ open trade routes to Byzantium, and also extend their territory westerward, with the help of Byzantium. Neverthelss, the reality was that Byzantium was still in touch with the Avars and even kept negotiations with the Sasanians open. The most important factor was that Byzantium did not fully trust the Western Türks. Hence, the Western Türks realized the role of "pawn« they had in the Byzantine "nomadic" policy, aiming at keeping the geopolitical balance on the Eurasian Steppes.

\section{Reviewing the relationship of the Western Türk and Byzantium}

In the preceding lines, the Western Türk-Byzantine diplomatic communication was resurveyed with the help of the Byzantine sources. The lines which follow are devoted to a review of the relationship of the two medieval polities and of the geopolitics along the Silk Road.

The middle of the 6th century to 7 th century was a crucial period. Great sedentary empires and nomads were active and interacting on the Silk Road, from the West to the East. The most important were the following: Avars, Byzantium, Western Türks, Sogdians, Persia, and also China. With the help of the Silk Road network they had relations and complicated interconnected interests in geopolitics, trade, cultural exchanges, religious ideas, etc. ${ }^{63}$

As to Byzantium in this period, it fell into a difficult phase. After experiencing the vigorous "reconquest" movement of Justinian, with the death of the great emperor, the empire fell into decline and crisis. On the one hand, these were internal issues: though Justinian's programme of reconquest enjoyed temporary success, it also exhausted the empire's resources. ${ }^{64}$ After Justinian's death, Byzantium was declining in economic, military and territorial terms. Simultaneously, the frequent occurrence of natural disasters and plagues led to the wane of the economy and a fall in the population, which resulted in military decline and a lack of troops at the borders. On the other hand, there were external issues: Byzantium faced serious challenges on its borders. The Italian territory was under threat from the Lombards; the northern border was being attacked by Avars and Slavs; ${ }^{65}$ and in the East the old enemy, the Persians, were still at war with Byzantium. ${ }^{66}$

The arrival of the Western Türk embassies to Byzantium in 560s brought new hope to Constantinople. First, the Western Türks were a strong military power holding an advantageous position on the Silk Road. Second, in 568, as a result of the Persian policy, they became the enemy of the Sasanians. Third, as a strong nomadic power, many minor nomads were subordinate to them, even the Avars who were active to the north of Byzantium. Pressure from the Western Türks on the latter would reduce Byzantium's problems with the Avars.

62 Nechaeva, "Runaway« Avars, 175-181.

63 The most recent works regarding the geopolitics on the Silk Road in this period are: Preiser-Kapeller, Jenseits; Pohl, Avars; Di Cosmo and Maas, Empires and Exchanges.

64 For the general condition of Justinian's time, please refer to: Parnell, Justinian's Men; Sarris, Economics and Society; Maas, Cambridge Companion; Cameron, Justin and Justinian, 63-85.

65 Pohl, Avars; Gandila, Cultural Encounters; Sarantis, Justinian's Balkan Wars.

66 Greatrex and Lieu, Roman Eastern Frontier. 
Fourth, the Sogdians, who were now under the protection of the Western Türks, were the main intermediary for trade along the Silk Road and it would also benefit the Western Türks to help Byzantium to open up its trade and communication with the East, thereby avoiding the Sasanian monopoly. ${ }^{67}$ Hence, Byzantium, which seemingly had a blurred understanding of grand strategy, ${ }^{68}$ managed to form an alliance with the Western Türks, using the latter to keep its strategy running.

As regards the Western Türks, after becoming the strongest nomadic power in Central Asia in the middle of the 6th century, they were eager to extend their influence. The Sogdians, who were subject to the Türks, also wanted to open up trade routes through areas in the Western Türks' power. However, the Sasanians were afraid of the Western Türks' expansion, which could affect their gains in trade, so they twice harshly rejected the proposals made by the Türk embassies sent by the Western Türks. Finally, following the suggestion of the Sogdians, the Western Türks managed to get in touch with Byzantium, an enemy of Persia and, at the time, in need of external help. The special relationship was soon established.

It is clear that the geopolitics between the 560 s and 580 s were not steady. The »honeymoon« of the alliance between Byzantium and the Türks did not last very long. The Western Türks, not receiving the gains they had hoped for from Byzantium, broke their alliance with it during the embassy of Valentinus. Why did this happened so fast? The reasons can be found in both societies. First, Byzantium never fully trusted the Western Türks. For the Byzantines, like the other nomads, the Western Türks were "superstitious, treacherous, foul, faithless, possessed by an insatiate desire for riches. They scorn their oath, do not observe agreements, and are not satisfied by gifts. Even before they accept the gift, they are making plans for treachery and betrayal of their agreements. They are clever at estimating suitable opportunities to do this and taking prompt advantage of them. They prefer to prevail over their enemies not so much by force as by deceit, surprise attacks, and cutting off supplies. $"{ }^{69}$ Hence, even while allying with the Türks, Byzantium always tried to be careful with them. Meanwhile, it continued its policy of relations with the Western Türks' enemy, the Avars. At the same time, by demonstrating to the Türks that the Byzantines knew how to produce silk, Byzantium aimed to stall the Sogdians' plans of extending silk trade in Byzantium. ${ }^{70}$ Another, even more serious reason is that Byzantium was still involved in negotiations with the Sasanians. ${ }^{71}$

The Byzantine behavior led to the Western Türks becoming disappointed with Byzantium, as demonstrated by the words of the Western Türks' Khagan Turxanthus, yelled at Valentinus: "Are you not those very Romans who use ten tongues and lie with all of them?...As now there are ten fingers in my mouth, so you Romans have used many tongues. Sometimes you deceive me, sometimes my slaves, Uarkhonitai. In a word, having flattered and deluded all

67 For the history and role of the Sogidians on the Silk Road, see Vaissière, Sogdian Traders; Naymark, Sogdiana.

68 "Grand Strategy« is a modern military term first introduced into Byzantine studies by Edward Luttwak in his Grand Strategy of the Byzantine Empire. His attitude is debated by Byzantinists, see Cameron, Thinking with Byzantium, 40-42.

69 Maurice, Strategikon, ed. Dennis and Gamillscheg, 360; Maurice, Strategikon, trans. Dennis, 116.

70 "When King Justin afterwards showed the Turks how the worms were bred and how silk was made, he greatly surprised them, since at that time they had possession of the markets and harbors of the Seres, formerly held by the Persians«, in Photius, Myriobiblon, PG 103, 137; Photius, Library, trans. Freese, 74.

71 The Byzantino-Persian relations in this period refers to Greatrex and Lieu, Roman Eastern Frontier. 
the tribes with your various speeches and your treacherous designs, when harm descends upon their heads you abandon them and take all the benefits for yourselves. You envoys come to me dressed with lies, and he who has sent you deceives me equally. « $^{72}$ The Western Türks felt that they were cheated by Byzantium and that they were used only to restrain the Sasanians and other nomadic powers. In consideration of the above issues, it is understandable why the Western Türks broke their alliance with Byzantium.

After Valentinus' embassy, relations between the Türks and Byzantium were abruptly cut off; however, this was not the end. According to the records of John of Ephesus and Michael the Syrian, the Western Türks attacked the rear of the Avars when the latter sacked the city of Anchialos in the Balkans in 584. Some scholars believe that this is because the Byzantine emperor Maurice resumed relations with the Western Türks. ${ }^{73}$ In addition, according to the records of Theophylact Simocatta, in the 590s, the Western Türk Khagan designated envoys to send an official letter to the Byzantine emperor Maurice to show his victories, and it is hard to say what the Türks' real purpose was. ${ }^{74}$ Furthermore, in 625-626, when the Byzantine emperor Heraclius fought against the Sasanians, a group of Western Türks allied with the Byzantines. ${ }^{75}$ The new condition of the relationship was due to the fact that, at that time, Byzantium began an offensive against the Sasanians, while the Western Türks were also at war with the Sasanians. ${ }^{76}$

Throughout the various stages that the Western Türk-Byzantine relations went through, one can find the basic characteristics of the geopolitics along the Silk Road during this period: on the one hand, the superpowers of the time aimed to keep their border in peace and achieve further gains (for example opening the pathway to the East) by adopting what could be called an Eurasian policy, ${ }^{77}$ in which the nomadic people were to be used for strategic purposes. ${ }^{78}$ At the same time, the balance of power among the nomads was also a crucial factor that needed to be regulated. On the other hand, the nomadic peoples tried to realize their own interests by playing the superpowers off against each other. If their interests could not be satisfied, they would move to another superpower, establishing ephemeral alliances. Overall, the Silk Road provided a field upon which different powers came to play, each pursuing their own interests, with geopolitics being intertwined and highly volatile.

72 Menander Protector, History, ed. Blockley, 173-175.

73 John of Ephesus, Ecclesiastical History, trans. Smith 260; Kardaras, Byzantium and the Avars, 53; Tzimou, Byzantine-Türk alliance, 9; Michel le Syrien, Chronique, trans. Chabot, 363.

74 Theophylact Simocatta, Historiarum, ed. Bekker, 281-282; Theophylact Simocatta, History, trans. Whitby and Whitby, 188, 191.

75 Nikephoros, Short History, ed. Mango, 54-55; Theophanes Confessor, Chronographia, ed. Classen, 485; Theophanes Confessor, Chronicle, trans. Mango and Scott, 446.

76 Evagrius Scholasticus, Ecclesiastical History, trans. Whitby, 307, footnote 59.

77 Mark Whittow believes that Byzantium pursued a Eurasian policy which could be observed through the relations of Western Türks and Byzantium, see Whittow, Byzantium's Eurasian Policy, 271-286.

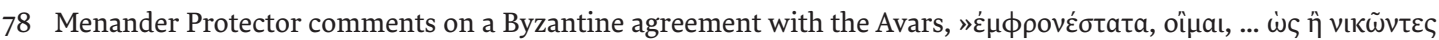

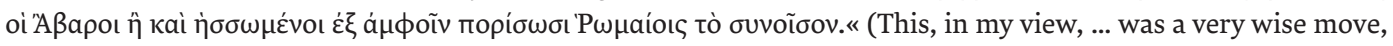
since whether the Avars prevailed or were defeated, both eventualities would be to the Romans' advantage), see Menander Protector, History, ed. Blockley, 50-51. 


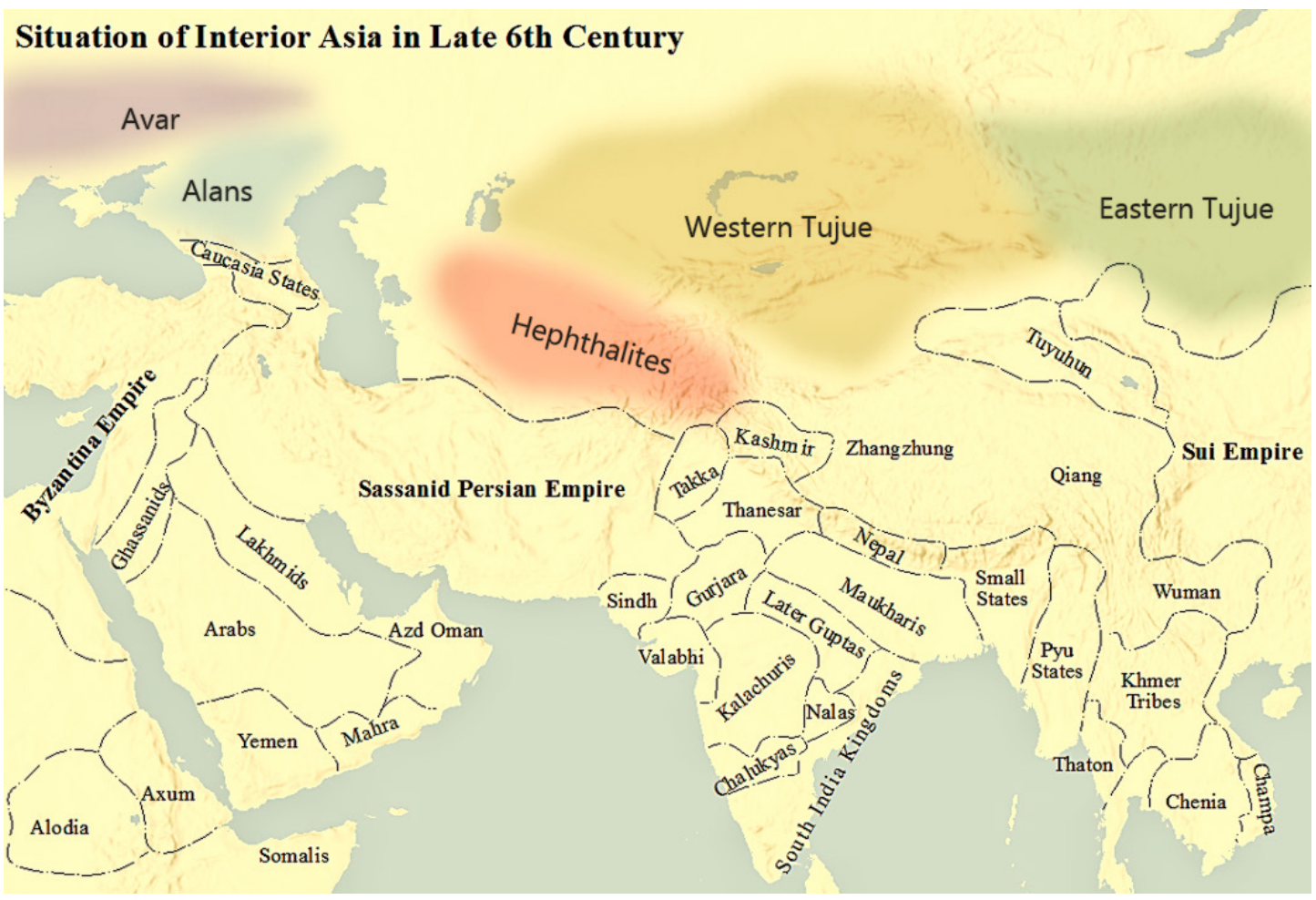

Figure 1: Interior Asia in the late 6th Century

\section{Acknowledgments}

We would like to express our gratitude to the valuable suggestions of the anonymous reviewers and Professor Pohl, as well as to the proofreader for her help with the English.

This article is sponsored by the general program of the National Social Science Fund of China "A Study on the Imitations of Byzantine Gold Coins and the Early Byzantine Luxuries Economics «(16BSS007), the key program "Research of Byzantine History and Culture" (14ZDB061), and also the Fundamental Research Funds for the Central Universities (16QNo11). 


\section{References}

Cameron, Averil, Justin and Justinian, in: Averil Cameron, Bryan Ward-Perkins and Michael Whitby (eds.), The Cambridge Ancient History, XIV, Late Antiquity. Empire and Successors, A. D. 425-60o (New York, 2000).

Cameron, Averil, Thinking with Byzantium, Transactions of the RHS 21 (2011) 39-57.

Chavannes, Édouard, Documents sur les Tou-kiue Occidentaux (Paris, 1903).

Corippus, In Laudem Iustini Augusti minoris, ed. Averil Cameron (London, 1976).

Di Cosmo, Nicola, and Maas, Michael, Empires and Exchanges in Eurasian Late Antiquity (Cambridge, 2018).

Erdemir, Hatice Palaz, The Nature of Turko-Byzantine Relations in the Sixth Century AD, Türk Tarih Kurumu, Belleten LXVIII/252 (2004) 423-430.

Evagrius, The Ecclesiastical History of Evagrius with the Scholia, ed. Joseph Bidez and Leon Parmentier (London, 1898).

Evagrius Scholasticus, The Ecclesiastical History of Evagrius Scholasticus, translated with an introduction by Michael Whitby (Liverpool, 2000).

Frankopan, Peter, The Silk Roads. A New History of the World (New York, 2016).

Frendo, David, The Turkish Factor in Byzantine-Iranian Relations (558-628), Türkleronline. Retrieved on 28 August 2018: www.turkleronline.net/turkler/makaleler/turkish_factor_ iran_bizans.htm\#_edn72.

Gandila, Andrei, Cultural Encounters on Byzantium's Northern Frontier, c. AD 500-70o (New York, 2018).

Greatrex, Geoffrey, and Lieu, Samuel N. C., The Roman Eastern Frontier and the Persian Wars $A D$ 363-628 (London, 2002).

Golden, Peter, Imperial Ideology and the Sources of Political Unity Amongst the Pre-Činggisid Nomads of Western Eurasia, Archivum Eurasiae Medii Aevi II (1982) 37-76.

Golden, Peter, Nomads and Their Sedentary Neighbors in Pre-Činggisid Eurasia, Archivum Eurasiae Medii Aevi VII (1987-1991) 41-81.

Golden, Peter, An introduction to the history of the Turkic peoples: Ethnogenesis and state-formation in medieval and early modern Eurasia and the Middle East (Wiesbaden, 1992).

Grousset, René, The Empire of the Steppes, translated from French by Naomi Walford (New Jersey, 1970).

Hansen, Valerie, The Silk Road. A New History (Oxford, 2015).

John of Ephesus, The Third Part of the Ecclesiastical History of John Bishop of Ephesus, translated by Robert Payne Smith (Oxford, 1860).

John of Epiphania, Johannes Epiphaniensis Fragmenta, ed. Carl Müller, Fragmenta historicorum Græcorum. Apollodori bibliotheca cum fragmentis, 4 (Paris 1851) 272-276.

John of Epiphania, History of the submission of Chosroës the Younger to Maurice the Roman Emperor by John of Epiphania the Scholastic and the Expraefectus, translated by Scott Kennedy. Retrieved on 08 August 2018: www.tertullian.org/fathers/john_of_epiphania.htm.

Kardaras, Georgios, Byzantium and the Avars, from 6th to the 10th Century [To BuZávtıo kaı ol 'A $\beta a \rho o$, $\Sigma T$ '- $\Theta$ ' al] PhD Thesis (University of Ioannina, 2007).

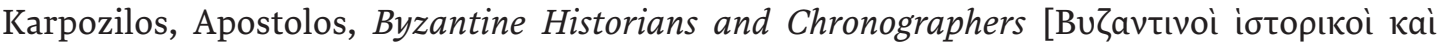

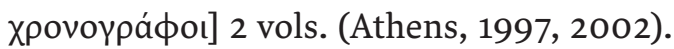

Kordosis, Stefanos, Byzantine-Turkic relations and the wider Eurasian alliances, during the Perso-Byzantine wars, International Journal of Eurasian Studies 2 (2011) 296-312. 


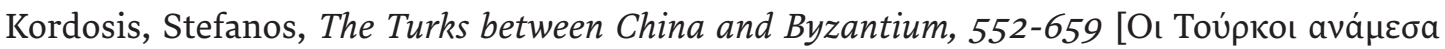

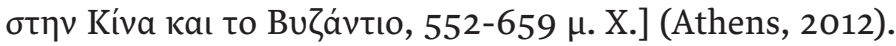

Kurbanov, Aydogdy, The Hephthalites: archaeological and historical analysis. Unpublished $\mathrm{PhD}$ Thesis (Freie Universität Berlin, 2010).

Litvinsky, Boris Anatol'evich, The Hephthalite Empire, in: Boris Anatol'evich Litvinsky, Zhang Guang-da and R. Shabani Samghabadi (eds.), History of Civilizations of Central Asia: The Crossroads of Civilizations, A.D. 250 to 750 (Paris, 1996) 138-165.

Liu, Xinru, The Silk Road in World History (New York, 2010).

Luttwak, Edward, Grand Strategy of the Byzantine Empire (New York, 2011).

Maas, Michael, The Cambridge Companion to the Age of Justinian (Cambridge, 2005).

Macartney, Carlile Aylmer, On the Greek Sources for the History of the Turks in the Sixth Century, Bulletin of the School of Oriental and African Studies 11/2 (1944) 266-275.

Maurice, Maurice's Strategikon, translated by George. T. Dennis (Philadelphia, 1984).

Maurice, Das Strategikon des Maurikios, ed. George T. Dennis and Ernst Gamillscheg, Corpus Fontium Historiae Byzantinae 17 (Wien, 1981).

Menander Protector, The History of Menander the Guardsman: Introductory Essay, Text, Translation, and Historiographical Notes, ed. and trans. by Roger C. Blockley (Liverpool, 1985).

Michel le Syrien, Chronique de Michel le Syrien Patriarche Jacobite d'Antioche (1166-1199), translated by Jean B. Chabot, 2 (Paris, 1901).

Moravcsik, Gyula, Byzantinoturcica (Leiden, 1983).

Nechaeva, Ekaterina, The "Runaway" Avars and Late Antique Diplomacy, in: Ralph W. Mathisen and Danuta Shanzer (eds.), Romans, Barbarians, and the Transformation of the Roman World: Cultural Interaction and the Creation of Identity in Late Antiquity (Burlington, 2011) 175-181.

Naymark, Aleksandr, Sogdiana, its Christians, and Byzantium. A Study of Artistic and Cultural Connections in Late Antiquity and Early Middle Ages. Unpublished PhD thesis (Bloomington, 2001).

Nikephoros Patriarch of Constantinople, Short History, text, translations, and commentary by Cyril Mango (Washington D. C., 1990).

Nikolay, Kradin, From Tribal Confederation to Empire: the Evolution of the Rouran Society, Acta Orientalia Academiae Scientiarum Hungaricae 58/2 (2005) 149-169.

Ouyang, Xiu and Song, Qi, New Book of Tang. Retrieved on 25 October 2018: chinesenotes. com/xintangshu.html.

Parker, Edward H., The Origin of the Turks, English Historical Review 11 (1896) 431-445.

Parnell, David Alan, Justinian's Men Careers and Relationships of Byzantine Army Officers, 518610 (London, 2017).

Photius, Myriobiblon Sive Bibliotheca, PG 103.

Photius, The Library of Photius, translated by John H. Freese (London, 1920).

Pohl, Walter, The Avars. A Steppe Empire in Central Europe, 567-822 (London, 2018).

Preiser-Kapeller, Johannes, Jenseits von Rom und Karl dem Großen. Aspekte der globalen Verflechtung in der langen Spätantike (Wien, 2018).

Ross, E. Denison, The Orkhon Inscriptions. Being a translation of Professor Vilhelm Thomsen's final Danish rendering, Bulletin of the School of Oriental Studies, 5/4 (1930) 861-876.

Sarantis, Alexander, Justinian's Balkan Wars. Campaigning, Diplomacy and Development in Illyricum, Thrace and the Northern World A.D 527-65 (Prenton, 2016).

Sarris, Peter, Economy and Society in the Age of Justinian (Cambridge, 2006). 
Sinor, Denis, The Establishment and Dissolution of the Türk Empire, in: Denis Sinor (ed.), The Cambridge History of Early Inner Asia (Cambridge, 1990) 285-316.

Sinor, Denis, The First Türk Empire, in: Boris Anatol'evich Litvinsky, Zhang Guang-da and R. Shabani Samghabadi (eds.), History of Civilizations of Central Asia. The Crossroads of Civilizations, A.D. 250 to 750 (Paris, 1996) 321-330.

Theophanes Confessor, Theophanis Chronographia 1, ed. Johannes Classen, Corpus Scriptorum Historiae Byzantinae 24/1 (Bonn, 1839).

Theophanes Confessor, The Chronicle of Theophanes Confessor. Byzantine and Near Eastern History AD 284-813, translated by Cyril Mango and Roger Scott (Oxford, 1997).

Theophylact Simocatta, Historiarum libri octo, ed. Immanuel Bekker, Corpus Scriptorum Historiae Byzantinae 33 (Bonn, 1834).

Theophylact Simocatta, The History of Theophylact Simocatta. An English Translation with Notes, translated by Michael Whitby and Mary Whitby (Oxford, 1986).

Treadgold, Warren, The Early Byzantine Historians (New York, 2007).

Treadgold, Warren, The Medieval Byzantine Historians (New York, 2013).

Tzimou, Georgia, The Byzantine-Türk Alliance from 563-628: Political and Economic Repercussions on the Balkan and Middle Eastern Frontiers of Byzantium. Unpublished MA Thesis (International Hellenic University, 2016).

de la Vaissière, Étienne, Sogdian Traders: A History (Leiden, 2005).

Whitby, Michael, The Successors of Justinian, in: Averil Cameron, Bryan Ward-Perkins and Michael Whitby (eds.), The Cambridge Ancient History, XIV, Late Antiquity. Empire and Successors, A. D. 425-60o (New York, 2000).

Whittow, Mark, Byzantium's Eurasian Policy in the Age of the Türk Empire, in: Nicola Di Cosmo and Michael Maas (eds.), Empires and Exchanges in Eurasia Late Antiquity (New York, 2018) 271-286.

Zhang, Xushan, Studies on the Relations between China and the Byzantine Empire [中国与拜占 庭帝国关系研究] (Beijing, 2012).

\section{List of figures}

Figure 1: Situation of Interior Asia in late 6th Century. Retrieved on 10 November 2018: commons.wikimedia.org/wiki/File:Interior_Asia_6th_century.png; SY [CC BY-SA 4.0 (creativecommons.org/licenses/by-sa/4.o)], from Wikimedia Commons. 